Justyna Kurbiel

\title{
Sztuka wobec Zagłady w warszawskich galeriach po 1989 r. Rekonesans
}

Spróbujmy usystematyzować formy obecności tematu Zagłady w sztuce prezentowanej w warszawskich galeriach. $Z$ jednej strony są to ekspozycje dokumentacyjne. Pokazują przebieg Zagłady, jej poszczególne etapy („Zagłada Romów europejskich i rasizm we współczesnej Europie”) czy dokumentują pamiątki i wspomnienia po ofiarach Holokaustu („I ciągle widzę ich twarze”). Zdarza się też, że są głosem ocalonych, którzy w swojej twórczości odnoszą się do tych tragicznych wydarzeń, jak w przypadku twórczości Samuela Willenberga, Gustava Metzgera czy części prac Daniela Libeskinda. Świadomie zostały pominięte pojedyncze prace podejmujące temat Holokaustu, prezentowane na wystawach monograficznych, takie jak Obóz koncentracyjny Lego Zbigniewa Libery, po raz pierwszy zaprezentowany w Polsce w 2009 r. Nie odmawiam oczywiście wartości dziełom, przegląd ten ma jednak na celu pokazanie podejścia do Zagłady jako tematu, a niekoniecznie wskazanie, którzy artyści temat podejmowali.

Przeważająca większość wystaw organizowanych od 1989 r. prezentuje prace artystów, których Zagłada dotyczy pośrednio - przez pamięć historyczną i zapośredniczone relacje. Często posługują się Holokaustem, by mówić o pamięci i zapomnieniu/zapominaniu (Jadwiga Sawicka i Joan Grossman, Joanna Rajkowska, Mirosław Bałka), relacjach polsko-żydowskich (Yael Bartana, Zofia Lipecka, Rajkowska, Public Movement) czy Zagładzie jako pęknięciu w kulturze zachodnioeuropejskiej, wydarzeniu niewyrażalnym i trudnym do ujęcia w porządku innym niż metaforyczny („Gdzie jest brat twój, Abel?”, Projekt „Próżna”, twórczość Metzgera, projekt Łukasza Rondudy).

Wszystkie te narracje w różnym stopniu znalazły reprezentacje w warszawskich instytucjach publicznych. 


\title{
Narodowa Galeria Sztuki „Zachęta” w latach 1995-2010*
}

\author{
„Gdzie jest brat twój, Abel?”, 7 maja-20 sierpnia 1995 r., kurator: Anda \\ Rottenberg
}

Magdalena Abakanowicz, Ttum I i Ttum III; Mirosław Bałka, Korytarz mydlany; Christian Boltanski, Ciemnia; Miriam Cahn, To, co na mnie patrzy; Marek Chlanda, Do widzenia; Ian Hamilton Finlay, Inskrypcje; Jochen Gerz, EXIT/The Dachau Project; Anselm Kiefer, Złoto Renu; Tomasz Kizny, Fotografie z budowy utopii; Jannis Kounellis, bez tytułu, ambalaże; Mosche Kupferman, bez tytułu, obrazy monochromatyczne; Władimir Kuprijanow, Etyka pozytywna; Gabriel Orozco, Moje dłonie sa moim sercem; Arnulf Rainer z cyklu Hiroszima; Antonio Saura, dwa Ukrzyżowania i Wielki ttum; Micha Ullman, Stót 4 i Stót 8, Lawrene Weiner, MOKRY PIASEK \& MAŁE KAMYKI/UMIESZCZONE NA SŁOŃCU, ABY WYSCHŁY (ZMIESZANE RAZEM); Krzysztof Wodiczko, Rzecznik i Laska tułacza; Penny Yassour, Przestrzeń domyślna.

Ta monumentalna wystawa składała się z prac 20 artystów z całego świata. Wystawa obejmowała nie tylko problem ludobójstwa. Tytułowe pytanie zostało zadane również z myślą o winie, odpowiedzialności i pamięci. We wstępie do katalogu Anda Rottenberg pisała: „Kiedy pytamy o Abla, myślimy o Kainie. To jego postać i jego dramat wyeksponowała Księga Rodzaju. To on [...] jest skazany na pamięć o podwójnej zbrodni: bratobójstwa i nieposłuszeństwa"1. Pytanie o Abla nie tylko odnosi się do zbrodniczego czynu, lecz także do osoby, której już nie ma, do brata, który padł ofiarą morderstwa. Pytanie skierowane do zabójcy nie tylko nadaje mu piętno winy, ale też nakłada obowiązek pamiętania - obciąża sumienie, będące nie tylko sumieniem tego, który miał krew na rękach, ale i potomków zachowujących pamięć o zbrodni. Jak pisał Karl Jaspers, wina jest przypisana każdemu z nas, ocalonych $^{2}$. Ekspozycja zorganizowana w rocznicę zakończenia drugiej wojny światowej niewątpliwie stawiała pytanie o związek sztuki z etyką i powracała do pytania Theodora Adorno: „Czy możliwa jest sztuka po Holokauście?”. Nie bez powodu w katalogu wystawy został przywołany fragment tekstu Doreet LeVitte Harten, piszącej o różnych próbach sformułowania języka sztuki, który byłby w stanie opisać Holokaust. Wspomina o chybionych próbach estetyzacji Zagłady i błędach w rozu-

* Wszelkie informacje na temat wymienionych ekspozycji zaczerpnęłam z archiwum dostępnego na stronach internetowych „Zachęty”: http://www.zacheta.art.pl/index. php?lang=1\&archives=1, dostęp 17 X 2011 r., oraz z wydanych drukiem katalogów:

- Gdzie jest brat twój, Abel?/Where is Abel, thy brother?, red. Tersa Rostkowska, Warszawa: Galeria Sztuki Współczesnej Zachęta, 1995.

- Problemy z pamięcia, Joan Grossman, Jadwiga Sawicka, Warszawa: Galeria Sztuki Współczesnej Zachęta, 2002.

- Gustav Metzger, wybór Hanna Wróblewska, Warszawa: Zachęta Narodowa Galeria Sztuki, 2007.

${ }^{1}$ Gdzie jest brat twój, Abel?...

${ }^{2}$ Karl Jaspers, Problem winy, tłum. Jan Garewicz, „Etyka” 1979, nr 17, s. 143-207. 
mieniu sztuki jako doznania zmysłowego w tym kontekście. Krytykuje też sztukę dokumentacyjną, która w jej mniemaniu stała się sztuką złą. W swoich rozważaniach dochodzi do twórczości poddającej pod rozwagę problem pamięci i prowadzącej do sublimacji fragmentaryczności jako głównego wyznacznika relacji o Zagładzie, które stało się równocześnie problemem powojennej historiozofii³

\section{„I ciaggle widzę ich twarze. Fotografia Żydów polskich” 18 kwietnia-4 maja 1996 oraz 6 września-3 października 2006 r.}

Gołda Tencer - autorka projektu, Tomasz Tomaszewski - komisarz wystawy, Krzysztof Burnatowicz - projektant wystawy, współtwórcy projektu: Anna Bikont, Krystyna Bratkowska, Tadeusz Grabowski, Ryszard Marek Groński, Jan Jagielski, Alina Jankowska, Marcel Łoziński, Lech Majewski, Małgorzata Niezabitowska, Irene E. Pipes, Szymon Szurmiej.

W 1994 r. Fundacja Shalom zaapelowała o nadsyłanie zdjęć Żydów polskich. Apel zaowocował wystawą prezentowaną w galerii w 1996 r., następnie ekspozycja gościła w wielu instytucjach na całym świecie, by po 10 latach powrócić do Zachęty. Jest to zbiór zwykłych fotografii - zdjęć rodzinnych, scenek rodzajowych i portretów mieszkańców polskich miast i miasteczek, którzy wojny nie przeżyli przez „złe pochodzenie rasowe". Do 2006 r. na apel odpowiedziało ponad 9 tys. ludzi w różnym wieku (od 12 do 90 lat) ${ }^{4}$. Jak mówiła autorka projektu Gołda Tencer, celem było ocalenie pamięci - właśnie przez pokazanie ogromu tragedii i jej bezpośredniego związku $\mathrm{z}$ losem tak wielu ludzi ${ }^{5}$. Wystawie towarzyszyło wydanie albumu z fotografiami, a także projekt stałej ekspozycji zdjęć w siedzibie Fundacji Shalom.

\section{Jadwiga Sawicka, Joan Grossman, „Kłopoty z pamięcią”, 16 listopada 2002-} 5 stycznia 2003 r., kurator: Hanna Wróblewska

Problemy z pamięcią czy też „przypadki pamięci” to wspólny projekt artystyczny Jadwigi Sawickiej i Joan Grossman. Obrazy wideo to zapis sentymentalnej podróży Joan Grossman w poszukiwaniu utraconych korzeni. Ukazywały ulice dzisiejszego Sokołowa Podlaskiego i jego okolic, a także Warszawy, Treblinki, Puszczy Białowieskiej, widziane $\mathrm{z}$ tego samego punktu, ale w różnych kierunkach. Paradoksalnie jednak nie to, co widać, jest tu głównym tematem, lecz to, czego nie ma i czego nie sposób odtworzyć, choć można przeczuć. Część bliskich Grossman przed wojną wyemigrowała z Sokołowa, co ocaliło ich od Zagłady, niestety nie uniknęła jej pozostała w miasteczku rodzina.

Projekcji towarzyszyły prace Jadwigi Sawickiej: powielone wydruki malarskie, pokrywające jak tapeta ściany ogromnej sali. Wydruki z odwzorowaną treścią, która zwykle wypełnia kartki kalendarza: przypomnienia o rocznicach, imieninach, sezonowych czynnościach, horoskopy i dowcipy. Powielone wielokrotnie, tak jak powta-

\footnotetext{
${ }^{3}$ Gdzie jest brat twój, Abel?...

${ }^{4}$ http://www.shalom.org.pl/index.htm, dostęp 17 X 2011 r.

${ }^{5}$ Ibidem.
} 
rzają się co rok te same dni i miesiące. Obok wydruków pokazano fotografie starych ubrań, jakby opuszczonych przez swych właścicieli, lecz ciągle jeszcze zachowujących ich kształty, mimowolną pamięć o ciałach, które je kiedyś wypełniały.

\section{„Treblinka. Rzeźby więźnia Samuela Willenberga”, 23 kwietnia-4 maja 2003 r.,} kurator: Małgorzata Bogdańska-Krzyżanek

Galeria Zachęta we współpracy z Ambasadą Izraela w Warszawie zorganizowała wystawę prac Samuela Willenberga, izraelskiego rzeźbiarza, więźnia i uciekiniera z obozu koncentracyjnego w Treblince. Złożyło się na nią 15 rzeźb z brązu i 3 rysunki, które odzwierciedlają tragiczne wspomnienia artysty. Prace: Młoda kobieta, Ojciec rozsznurowujący dziecku buty, Inwalida, Wyjście Żydów z wagonu na peron obozu w Treblince, Rozebrane kobiety, Wynoszenie zmartych w czasie transportu, Flaschen sortieren, Obłąkana dziewczynka, Więzień sortujacy do walizek rzeczy po zagazowanych, Szajsmajster, Artysta malarz, Obozowa orkiestra Artura Golda, Bunt więźniów.

\section{Daniel Libeskind, „Fundamenty pamięci/Memory Foundations”, 15 czerwca- 15 sierpnia 2004 r., kurator: Gabriela Świtek}

Tytuł wystawy w Zachęcie, „Fundamenty pamięci/Memory Foundations”, odnosił się do najnowszego projektu Daniela Libeskinda - odbudowy World Trade Center w Nowym Jorku (od 2003 r.). Na wystawie pokazany został model ekspozycyjny World Trade Center oraz jeden z modeli Muzeum Żydowskiego w Berlinie (1988-2001) - tzw. model z nazwiskami.

\section{„Zagłada Romów europejskich i rasizm we współczesnej Europie”,}

31 października-26 listopada 2006 r., kuratorzy: Joanna Talewicz-Kwiatkowska, Marek Isztok

Wystawa (wchodzące w jej skład eksponaty - dokumenty, fotografie, dowody tożsamości - pochodziły od kilkudziesięciu instytucji, a także osób prywatnych zaangażowanych w realizację tego przedsięwzięcia) została podzielona tematycznie na cztery części według historycznej chronologii: dojście narodowych socjalistów do władzy i pierwsze deportacje do obozów koncentracyjnych, ludobójstwo dokonane na Romach w okupowanej przez nazistów Europie, ludobójstwo w Auschwitz-Birkenau, sytuacja mniejszości romskiej po 1945 r. Jest to projekt z założenia informacyjny: „Ekspozycja ma na celu przybliżenie wiedzy o holokauście Sintich i Romów. Członków tej społeczności, od niemowlęcia po starców, tak samo jak Żydów, prześladowano na podstawie nazistowskiej ideologii rasowej - pozbawiano praw, zamykano w gettach i ostatecznie deportowano do obozów zagłady” - czytamy w katalogu ${ }^{6}$.

${ }^{6}$ http://www.zacheta.art.pl/index.php?archiveexhibitions=1\&id=332\&lang=1\&archives= 1\&div=1, dostęp 17 X $2011 \mathrm{r}$. 
Gustav Metzger, „Prace 1995-2007”, 6 marca-22 kwietnia 2007 r., kuratorzy: Pontus Kyander, Hanna Wróblewska, współpraca Julia Leopold, realizacja Anna Muszyńska

Wystawa obejmowała cztery sale, z których każda była rozdziałem w narracji. „Pola śmierci” to odniesienie do filmu Rolanda Joffe’a o wydarzeniach w Kambodży. Ekspozycja składała się z ogromnej, rozrastrowanej, ale wciąż rozpoznawalnej fotografii przedstawiającej rampę w Auschwitz - transport i selekcję Żydów węgierskich w 1944 r. W sali znajdowały się obiekty z cyklu „Fotografie historyczne”, nawiązujące do różnych wydarzeń XX w.: Anschlussu Austrii w 1938 r., zamachu bombowego w Oklahoma City w 1995 r., bombardowania napalmem ludności cywilnej w Wietnamie w 1972 r., wydarzeń z historii konfliktu arabsko-izraelskiego czy katastrofy ekologicznej - zniszczenia przyrody w wyniku przeprowadzenia autostrady w Twyford Down w Anglii. Kolejna sala, „In memoriam”, zawierała pracę Likwidacja getta warszawskiego, 19 kwietnia - 28 dni, 1943 ze słynną fotografią z raportu Jürgena Stroopa dowodzącego likwidacją, zabudowaną szczelnie surowymi deskami. Zaprezentowano też instalację z 2006 r. pod tym samym tytułem. Ogromne kartonowe pudła, ustawione w rzędach, nawiązywały do berlińskiego pomnika Pomordowanym Żydom Europy autorstwa Petera Eisenmanna. Następne pomieszczenie, „Terror i Opresja” - ówcześnie najnowsza praca z cyklu „Fotografie historyczne”, powstała specjalnie na wystawę w Zachęcie. Tworzyły ją dwie wiszące naprzeciw siebie ogromne fotografie: Żydzi w równych szeregach stojący w kolejce do rejestracji w Buchenwaldzie w 1938 r. i Niemcy w równych szeregach wkraczający do Polski w 1939 r. Ofiara i kat - przedstawieni w podobnym szyku i porządku. Narrację wystawy zamykała wielowątkowa instalacja Eichmann i anioł z 1995 r. Odtworzona klatka, w której siedział Eichmann podczas swojego procesu w Jerozolimie, stała naprzeciwko ściany z gazet (w oryginale był to „Guardian”, w Zachęcie - „Rzeczpospolita”). Wzdłuż drugiej, dłuższej ściany ustawiony był pas transmisyjny, a przed nim paczki gazet pozostałych po budowie ściany. Każdy z widzów mógł rozłożyć egzemplarz i położyć na przesuwającym się pasie. Machina przemieszczała gazetę, która w końcu lądowała na podłodze na stosie innych „zużytych” gazet. „Bezimienna, masowa, bezsensowna produkcja chaosu i zniszczenia trwa”. Na ścianie reprodukcja obrazu Angelus Novus Paula Klee. Obraz ten był własnością Waltera Benjamina.

\section{Krystyna Piotrowska „Dokumenty podróży”, 7-24 marca 2008 r.}

Wystawa złożona jest niemal wyłącznie z projekcji wideo, są to wywiady z Polakami żydowskiego pochodzenia, którzy w 1968 r. zostali zmuszeni do wyjazdu z Polski. Otrzymywali oni wtedy nie paszporty, ale tzw. dokumenty podróży, które działały tylko w jedną stronę. Artystka prosiła rozmówców, by jak najzwięźlej dokończyli zdanie: „Wyjechałem, wyjechałam z Polski, bo...”. I powtórzyli to samo zdanie w języku kraju, w którym się osiedlili. Częścią wystawy było stanowisko multimedialne z komunikatorem internetowym, dzięki któremu można było zadzwonić lub napisać do bohaterów filmu Krystyny Piotrowskiej. 
Zofia Lipecka, „Po Jedwabnem”, 8 marca-18 maja 2008 r., kurator: Hanna Wróblewska

Pokaz wideoinstalacji artystki z polskim rodowodem, mieszkającej na stałe we Francji, był rodzajem artystycznego głosu w dyskusji, reakcją na książkę Jana Tomasza Grossa Sąsiedzi, wydaną w 2000 r. W niewielkiej przestrzeni Lipecka przedstawiła równolegle cztery projekcje (po dwie naprzeciw siebie), pomnożone dodatkowo niemal w nieskończoność przez odbijające je lustra, wiszące na dwóch innych ścianach. Filmy ukazywały prezentowane w dużym zbliżeniu twarze ludzi, ich reakcje na przeczytany fragment tekstu książki Grossa - świadectwo Szmula Wasersztajna o pogromie w Jedwabnem. Z głośników docierał szum, z którego wyraziście wyłaniał się czytany tekst świadectwa. Widzowie otoczeni przez projekcje mieli stać się częścią tej instalacji, sami zmuszeni stanąć wobec problemu Zagłady. Samotni w zderzeniu z tekstem, projekcją i własnym odbiciem.

Yael Bartana, „Zamach”, 3 czerwca-21 sierpnia 2011 r., kuratorzy: Sebastian Cichocki, Galit Eilat

Zamach jest ostatnią częścią „polskiej” trylogii Bartany (składają się na nią wcześniejsze filmy: Mary Koszmary, 2007, Mur i wieża, 2009). Akcja Zamachu toczy się w niedalekiej przyszłości, podczas ceremonii pogrzebowej lidera Ruchu Odrodzenia Żydowskiego w Polsce, który ginie z rąk nieznanego zamachowca. Śmierć przywódcy scala mit nowego ruchu, którego działalność mogłaby przerodzić się w konkretną propozycję polityczną do wdrożenia w najbliższej przyszłości w Polsce, Europie, na Bliskim Wschodzie.

Yael Bartana, „... i zadziwi się Europa”, 4 czerwca-27 listopada 2011 r., 54. Międzynarodowa Wystawa Sztuki w Wenecji, komisarz pawilonu: Hanna Wróblewska, kuratorzy: Sebastian Cichocki i Galit Eilat, asystent komisarza: Joanna Waśko, organizator: Zachęta Narodowa Galeria Sztuki

Głównym tematem filmowej trylogii Yael Bartany jest działalność Ruchu Żydowskiego Odrodzenia w Polsce - wykreowanego przez artystkę ruchu politycznego, stawiającego sobie za cel powrót ponad 3 mln Żydów do ojczyzny ich przodków. Filmy te rozgrywają się w symbolicznej przestrzeni pełnej blizn po konfliktach etnicznych i wojnach, wiążą ze sobą wątki dotyczące izraelskiego ruchu osadniczego, syjonistycznych marzeń, antysemityzmu, Holokaustu i palestyńskiego prawa do ziemi. Filmy: Mary Koszmary, 2007; Mur i wieża, 2009; Zamach, 2011. Wystawie towarzyszy publikacja pod tytułem A Cookbook for Political Imagination, zawierająca zestaw politycznych instrukcji i przepisów. 


\section{Centrum Sztuki Współczesnej Zamek Ujazdowski w Warszawie* *}

Christian Boltanski, „Revenir”, 14 września-11 listopada 2001 r., kurator: Milada Ślizińska

Wystawa miała charakter retrospektywny. Autor, rosyjski Żyd, nawiązuje w swoich pracach do doświadczenia Zagłady, a także nieprzewidywalności i kruchości życia. W 2001 r. zaprezentowano prace: Monument, Reliquaire, Les Images Noires, Les Veronique, Théâtre d'Ombres, Reserve, Les Suisses Morts, oraz pracę przygotowaną specjalnie na wystawę w CSW Les Habitants de Varsovie. Wystawie towarzyszyła akcja billboardowa Witness, ponadto 13 września 2001 r. do stołecznego wydania „Gazety Wyborczej” dołączony został dodatek zaprojektowany przez artystę.

\section{„Wyobrażenia Holocaustu w realizacjach filmowych i video polskich artystów.} Archiwum Polskiego Filmu Eksperymentalnego”, 24 lutego 2006 r., kurator: Łukasz Ronduda

Artur Żmijewski, Lisa, 2003; Józef Robakowski, 6.000.000, 1961; Tomasz Kozak, Tadeusz Borowski edycja esencjalna, 2006; Tadeusz Makarczyński, Życie jest piękne, 1957; Maciej Toporowicz, Obsession, 1993; Artur Żmijewski, Berek, 1999; Zbigniew Libera, Iskra, 1984; Azorro, Les Figurants, 2005; Agnieszka Brzeżańska, Free Doom, 2004; Artur Żmijewski, 80064, 2004; Aleksandra Polisiewicz, IBM Dedicated, 2004; Rafał Jakubowicz, Arbeitsdisziplin, 2002; Elżbieta Janicka, Miejsce Nieparzyste, 2006; Mirosław Bałka, Winterreise (fragment), 2003.

Pokaz filmów oraz wideo dziesięciu polskich artystów podejmujących temat Zagłady. Próba podsumowania twórczości polskich artystów nawiązujących do Holokaustu świadczy o tym, że temat nie został zapomniany, wciąż istnieje potrzeba podejmowania go na nowo. Selekcja Rondudy był całkowicie subiektywna i wzbudziła wiele kontrowersji ${ }^{7}$. Dyskusja, która wybuchła po prezentacji, pokazała zarówno znaczenie, jak i drażliwość tego zagadnienia ${ }^{8}$.

\section{Joanna Rajkowska, „ZOSTAW TO!”, z cyklu „W samym centrum uwagi”, część 9, 17 lipca-3 września 2006 r., kurator: Magda Pustoła}

Seria działań wpisanych w przestrzeń CSW ogniskowała się wokół projektu instalacji Dotleniacz na placu Grzybowskim w Warszawie, który został ostatecznie

${ }^{* *}$ Wszelkie informacje dotyczące ekspozycji i wydarzeń zaczerpnęłam z archiwum dostępnym na stronach CSW: http://csw.art.pl/index.php?action=archiwum, dostęp $17 \mathrm{X}$ 2011 r., oraz druków ulotnych dotyczących wystawy Joanny Rajkowskiej „Zostaw to!”, udostępnionych przez Bibliotekę oraz Ośrodek Dokumentacji i Informacji Naukowej CSW.

${ }^{7}$ Katarzyna Bojarska, Rozmawiajmy poważnie - o projekcie kuratorskim „Wyobrażenia Holocaustu w realizacjach filmowych i video artystów polskich"; http://www.obieg.pl/recenzje/3931, dostęp 17 X $2011 \mathrm{r}$.

${ }^{8}$ Recepcja Holokaustu w sztuce - dyskusja w Zachęcie, 17 IV 2007 r., http://www.jewishmuseum.org.pl/pl/cms/aktualnosci/542/, dostęp 17 X 2011 r. 
zrealizowany w 2007 r. Był to staw o powierzchni $150 \mathrm{~m}^{2}$, głęboki na metr, produkujący bogatsze w tlen powietrze, świeże jak po burzy. Pozytywna energia stawu miała odmienić charakter placu Grzybowskiego, miejsca zapomnianego, nasyconego niechęcią, pozbawionego wyrazistej tożsamości, mimo że w jego przestrzeni przenikają się liczne narracje - ulica Próżna, Teatr Żydowski, kościół i działająca wówczas w jego podziemiach Księgarnia Patriotyczna Antyk sprzedająca wydawnictwa antysemickie, siedziba Deutsche Banku i inne nowoczesne biurowce, sklepiki z kranami i linami, powojenne bloki.

Prace Rajkowskiej zostały wplecione w pozostałe wystawy prezentowane w tym czasie w przestrzeni Zamku Ujazdowkiego oraz w przestrzeń miejską: Dotleniacz, plac Grzybowski; Literatura patriotyczna, Galeria Wejście; Maja Gordon jedzie do Chorzowa, Galeria Miejsce; Tu spocznij, Sala w Galerii 2; Pozdrowienia z Alej Jerozolimskich, Galeria Okna, rondo de Gaulle'a; Nie, baszta obok sali ekspozycyjnej w Galerii 2; Hello, półpiętro na klatce schodowej; W górę!, szatnia na parterze, obok schodów.

Mirosław Bałka, „Fragment”, 15 stycznia-3 kwietnia 2011 r., kurator: Marek Goździewski

Mirosław Bałka w swoich pracach jeśli nie odnosi się bezpośrednio do Zagłady, to za temat obiera sobie zagadnienia związane z przemijaniem czy problemem pamięci/niepamięci. Zaprezentowano prace wideo z lat 1998-2010: te, które przeszły już do klasyki sztuki współczesnej, w tym między innymi znany cykl trzech filmów z Brzezinki Winterreise (Staw, Bambi 1 i Bambi 2), ale też mniej znane, takie jak Narayama, Flagellare A,B,C czy ostatnia praca apple T. Ta ostatnia była też przedmiotem wykładu Georges’a Didi-Hubermana w Muzeum Sztuki Nowoczesnej 16 czerwca 2011 r.

\section{Muzeum Sztuki Nowoczesnej w Warszawie ${ }^{* * *}$}

Dzieła podejmujące tematykę Holokaustu w zbiorach Muzeum Sztuki Nowoczesnej w Warszawie:

\section{Mirosław Bałka, I Knew It Had 4 in It, 2008 r.}

Zrealizowany w duchu eksperymentalnej etiudy z lat siedemdziesiątych, wykorzystujący muzykę Sun Ra The All of Everything, film w sposób zakamuflowany odnosi się do cytatu z filmu Claude’a Lanzmanna Shoah: pytania o liczbę wymordowanych w czasie Holokaustu Żydów.

Praca w charakterystyczny dla artysty sposób podważa naszą powierzchowną wiedzę o świecie, sugerując, że tuż pod powierzchnią rzeczy czai się wyparte zło. Artysta widzi swoje zadanie w jego wskazywaniu, w przywracaniu bolesnych wspomnień, w nieustannym ćwiczeniu się w pamiętaniu.

${ }^{* * *}$ Informacje na temat zbiorów zaczerpnęłam ze strony internetowej MSN w Warszawie: http://www.artmuseum.pl/wydarzenie.php?id=3xTAK, dostęp 17 X $2011 \mathrm{r}$. 


\section{Yael Bartana, Mur i wieża (Wall and Tower), 2009 r.}

Mur i wieża to rozwinięcie wcześniejszego projektu artystki - filmu Mary Koszmary z 2007 r. W tamtej realizacji młody lewicowy aktywista (w tej roli Sławomir Sierakowski) przemawiał przy pustych trybunach Stadionu Dziesięciolecia, zachęcając 3 mln Żydów do powrotu do Polski. Był to głos w dyskusji na temat polskiego antysemityzmu, który doprowadził do wykluczenia wielu ludzi, jak to się zdarzyło w 1968 r. Odnosi się też do milionów ofiar Zagłady. Akcja Muru i wieży rozgrywa się na placu budowy „pierwszego kibucu w Europie”, w miejscu, gdzie ma stanąć budynek Muzeum Historii Żydów Polskich - na skwerze przed pomnikiem Bohaterów Getta. Artystka prezentuje hipotetyczny scenariusz, w którym żydowscy przybysze osiedlają się na polskich ziemiach, stosując procedury z lat trzydziestych, i rozpoczynają budowę kibucu.

\section{Oskar Dawicki, Nigdy nie zrobitem pracy o Holokauście (I Have Never Made a Piece About the Holocaust), 2009 r.}

Manifest artysty: biała kartka ze zdaniem głoszącym: „Nigdy nie zrobiłem pracy o Holokauście”. Praca podważająca dyskursy na temat Zagłady, obnażająca bezsilność wobec tematu oraz mechanizmy mód i trendów jako sił napędzających współczesny art world.

\section{Fundacja Galerii Foksal}

Fundacja Galerii Foksal niejednokrotnie organizowała ekspozycje artystów, których głównym obszarem zainteresowań jest Holokaust i zagadnienia wiązane są z nim jako kategoria filozoficzna, a także dyskurs pamięci, wyparcia i historii. Są to przede wszystkim Mirosław Bałka i Christian Boltanski. Ponadto Fundacja współorganizowała wydarzenia, które okazały się mieć duże znaczenie w dyskusji na temat recepcji Zagłady oraz podejścia społeczeństwa polskiego do historii.

\section{Mirosław Bałka}

April/My body cannot do everything I ask for (7 marca-8 kwietnia 1991 r.), 37,1 (19 stycznia-22 kwietnia 1993 r.), Pause (1 kwietnia-16 maja 1996 r.), a, e, i, o, u (27 marca-7 maja 1997 r.), sza (17 lutego-16 marca 1999 r.).

\section{Christian Boltanski}

Reserve (9 października-30 listopada 1989 r.), C.B. sa vie, son oeuvre/jego życie i dzieło (13 września-18 października 2001 r., wystawa towarzyszyła pokazowi prac Revenir w CSW), SERCE (21 lutego-8 maja 2008 r.). 
Artur Żmijewski, Polak w szafie, 4 kwietnia 2007 r., Fundacja Galerii Foksal, Fundacja im. Stefana Batorego

Film jest zapisem dyskusji grupy studentów prof. Joanny Tokarskiej-Bakir po powrocie z badań w Sandomierzu. Badania dotyczyły obrazu przedstawiającego Żydów dokonujących mordu rytualnego - grupa zastanawiała się nad obecnością obrazu w tamtejszej katedrze, a także stosunkowi miejscowej ludności od jego tematyki. Film pokazuje też podjętą przez grupę „pracę z obrazem” - działania warsztatowe prowadzone przez artystę i studentów w Centrum Sztuki Współczesnej w Warszawie.

Badania, realizacja filmu, a także debata po jego projekcji, w której udział wzięli: Helena Datner, Dariusz Karłowicz, Stanisław Krajewski, Zbigniew Nosowski, Joanna Tokarska-Bakir, Leszek Tyboń i Artur Żmijewski ${ }^{9}$, były związane z głośna książką Joanny Tokarskiej-Bakir Legendy o krwi. Antropologia przesądu.

\section{Yael Bartana, Mary Koszmary, 18 stycznia-29 lutego 2008 r.}

Film przedstawia przywódcę Ruchu Odrodzenia Żydowskiego w Polsce (w tej roli Sławomir Sierakowski), który wygłasza przemówienie na pustym Stadionie Dziesięciolecia, przekonując 3 mln Żydów, aby wrócili do Polski i ponownie tutaj zamieszkali, jako najbliżsi Polakom Inni.

\section{Z cyklu „Ideozy”: „Leszno/Świerczewskiego/Solidarności”, 29 maja-}

11 czerwca 2010 r., kuratorki: Agnieszka Szostakiewicz, Aleksandra Fedorowicz-Jackowska, Justyna Zielkowska, opieka merytoryczna: prof. Andrzej Turowski, projekt we współpracy z: Fundacją Galerii Foksal/Instytutem Awangardy, Muzeum Niepodległości, Instytutem Historii Sztuki Uniwersytetu Warszawskiego, Muzeum Sztuki Nowoczesnej w Warszawie ${ }^{10}$

Wystawa wpisywała się w znaczenie miejsca, w którym została zaprezentowana. Instytut Awangardy mieści się na terenie dawnego getta, o czym przypomniano, powtarzając akcję Artura Żmijewskiego i prof. Joanny Tokarskiej-Bakir - „Listy o głodzie”. Ponownie 14 maja 2010 r. kserokopia listu wysłanego w latach czterdziestych z getta warszawskiego z wołaniem o pomoc została zapakowana i puszczona w obieg z pytaniem, jak współcześni adresaci ustosunkowują się do niego, listy zostały włożone do skrzynek mieszkańcom bloków znajdujących się w sąsiedztwie Instytutu Awangardy. Wystawa, która była zakończeniem trwającego w roku akademickim 2009/2010 cyklu, miała też przywoływać koniec modernizmu - czyli właśnie doświadczenia Zagłady. Miejsce, którego obecni mieszkańcy nie utożsamiają już z gettem, posłużyło ponadto kuratorkom do zobrazowania pustki pozostałej po ofiarach. Jednym z zabiegów kuratorskich było włączenie w strukturę wystawy widoku z okien sali wystawienniczej z rozległą panoramą na dawne getto, którego śladów już nie widać.

${ }^{9}$ www.batory.org.pl/doc/Polak_w_szafie.pdf, dostęp 17 X 2011 r.

${ }^{10}$ http://ideozy.blogspot.com/2010/05/lesznoswierczewskiegosolidarnosci.html, dostęp 17 X 2011 r. 
Erna Rosenstein, „Mogę powtarzać tylko nieświadomie”, 13 maja-3 lipca 2011 r., Fundacja Galerii Foksal/Instytut Awangardy

Retrospektywna wystawa prac artystki związanej z Grupą Krakowską i nurtem surrealistycznym. Na twórczości artystki piętno wycisnęły losy wojenne i śmierć rodziców. Zarówno w wierszach, jak i w rysunkach powraca motyw krzyku matki, zabijanej przez szmalcownika. Stale powtarzają się motywy księżycowej nocy, noża (rysowanego bądź będącego częścią asamblażu), rozcinania skóry, wdarcia się w głąb ciała. Twarze rodziców stanowią niemal jedyny nieabstrakcyjny element rysunków. Tytuły nadawane niektórym przedmiotom i obrazom (Rocznica, Świecit księżyc) zdają się nawiązywać do tragedii.

\section{Projekty realizowane w przestrzeni miasta}

„Projekt Próżna”****, 2005-2009, kurator: Krystyna Piotrowska

Projekt w ramach festiwalu „Warszawa Singera”, realizowany pod patronatem Ministerstwa Kultury i Dziedzictwa Narodowego, Narodowej Galerii Sztuki Zachęta, Muzeum Historii Żydów Polskich, Fundacji Shalom, portalu Sztuka.pl

Zamierzeniem projektu było pokazanie, jak najnowszy język sztuki potrafi odnieść się do tej przeszłości i teraźniejszości, które przywołuje opozycja ul. Próżnej wobec otoczenia. Język sztuki współczesnej ma pokazać sposoby naturalizowania pamięci o zbrodni, a także mechanizmy działania pamięci społecznej i strategie pamięci indywidualnej, jak też mechanizmy wyparcia czy bagatelizowania.

\section{5:}

Krystyna Piotrowska, Luli, luli; Krystiana Robb-Narbutt, Sen Dawidka Rubinowicza

\section{6:}

Nelly Agassi Asunta i Face In; Dr Muto, Katrzyna Krakowiak, Łukasz Szałankiewicz, ASHAVER 220; Rafał Jakubowicz, Precz z żydowska sztuka i Piaskownica; Katarzyna Krakowiak, Chodnik i Waga; Ewa Kuryluk, Tabuś; Piotr Lachmann, Przejścia nie ma; Janusz Marciniak, Lustra - Zwoje; Waldemar Petryk, Elektoralna 13; Krystyna Piotrowska, Karp i Joga; Joanna Rajkowska, Literatura patriotyczna; Krystiana Robb-Narbutt, Fuga pamięci; Artur Żmijewski, Nasz śpiewnik.

\section{7:}

Nelly Agassi, Sen, gdzie cisza jest złotem; Mirosław Bałka, Kurtyna i Rauschsignales; Adina Bar, On History of Love - A Trilogy; Dr Muto, Katrzyna Krakowiak, Łukasz Szałankiewicz ASHAVER 220; Izabella Gustowska, Ponad wszystko; Rafał Jakubowicz, Cień i Meerschaum; Elżbieta Janicka, Miejsca nieparzyste; Jarosław Kozakiewicz, Puk, puk; Katarzyna Krakowiak, Rampa, Yifat Lajst, Marzenie Rindera,

\footnotetext{
${ }^{* * * *}$ Informacje o projekcie na stronie www.projektprozna.pl, dostęp 17 X 2011 r.
} 
Haim Maor, Oblicza rasy i pamięci i Echo chamber; Franciszek Orłowski, Papamobile; Krystyna Piotrowska, www.strefadowcipow.za.pl i Le Palais; Anna Płotnicka, Sprzedam dom, w którym już nie chcę mieszkać; Krystiana Robb-Narbutt, I know, it's not true that we lived; Tomasz Struk, bez tytułu.

\section{8:}

Jacek Adamas, Jonasz, Strażnik i Alef; Nelly Agassi, Sand It Better; Inga Fonar Cocos, Między ojczyznami; Wiktor Gutt, Gwiazda wybrana; Elżbieta Janicka, Zielnik (fragment kolekcji), Widokówki (fragment kolekcji) i Pieczątka (fragment kolekcji); Andrzej Kokosza, bez tytułu; Krystyna Piotrowska, Kapliczka i Dywan; Aleksandra Polisiewicz, Pułapki rzeczywistości; Ptski [Zygmunt Piotrowski], Tikkun Olam; Jadwiga Sawicka, Spodobało się jej: szalona; Tomasz Tatarczyk, Krok za krokiem; Artur Żmijewski, Oni.

\section{9:}

Hubert Czerepok, Człowiek; Oskar Dawicki, Nigdy nie zrobiłem pracy o Holokauście; Daniela Deutelbaum, Alt wird neu (Stare będzie nowe); Wojciech Doroszuk, Shalom Chantal; Ronen Eidelman, Zecher Lahaim, Ku pamięci żyjącym; Inga Fonar Cocos, TEL-AVIV-WARSAW NON STOP; Zuzanna Janin, Synagoga i Synagoga (2); Ryszard Kaczeczka, Próżne skrzynki na listy; Katarzyna Krakowiak, Sto lat później; PFŻGWwP, Stare będzie nowe; Krystyna Piotrowska, Oczy niebieskie; Katarzyna Podgórska, Glonti Makor i Pewnego dnia; Jan Rusiński, Stanisław Wójcik, Swietlik; Ewa Stawecka, Wiem, to nieprawda, że żyliśmy; Grzegorz Sztwiertnia, Action Painting; Waldemar Tatarczuk Byto. Jest. Nie będzie; Wojciech Wilczyk, Niewinne oko nie istnieje.

„WIOSNA W WARSZAWIE”, spacer przez getto pod przewodnictwem grupy Public Movement. Marsz, ceremonia, obchody, manifestacja i impreza, 18 kwietnia 2009 r., kurator: Joanna Warsza, produkcja: Zuza Sikorska. Akcja zorganizowana przez fundację Nowy Teatr we współpracy z CSW i Instytutem Adama Mickiewicza

Public Movement we współpracy z polskimi uczestnikami przeprowadziło mieszkańców Warszawy przez dawne getto trasą, którą przemierzają izraelskie i żydowskie delegacje młodzieży. Publiczność - około 1500 osób - zgromadziła się na Umschlagplatz i wspólnie przeszła ulicami Stawki, Miłą, Zamenhofa, biorąc udział w nowych rytuałach publicznych, wprowadzając $\mathrm{w}$ te miejsca inną energię i znaczenia symboliczne. Akcja zakończyła się ceremonią przy pomniku Bohaterów Getta. Polscy i izraelscy liderzy przemarszu byli ubrani w białe uniformy, nieśli flagi i kwiaty - powszechne insygnia władzy, wyzwolone jednak od komunikatu i jednoznaczności państwowych rytuałów. PM uwodzi mechanizmami tworzenia masowych widowisk, konsekwencją i synchronizacją; a jednocześnie dystansem do odgórnie sterowanych, antyindywidualnych uroczystości państwowych, roszczących sobie prawo do oficjalnej pamięci.

Członkowie grupy Public Movement: Dana Yahalomi, Omer Krieger, Luciana Kaplun, Adili Liberman, Gali Libraider, Hagar Ophir, Michael Rosman, Saar Szekely. 